\title{
KEMAMPUAN BERPIKIR KRITIS DALAM MENYELESAIKAN SOAL HIGH ORDER THINKING SKILLS (HOTS) PADA MATERIBILANGAN
}

\author{
Yuni Ekawati \\ STKIP PGRI Sidoarjo \\ yunieka409@gmail.com \\ Siti Nuriyatin \\ STKIP PGRI Sidoarjo \\ sitinuriyatin@gmail.com \\ Nurina Ayuningtyas \\ STKIP PGRI Sidoarjo \\ nurinaayu.n@gmail.com
}

\begin{abstract}
Abstrak
Berpikir kritis merupakan kegiatan yang memerlukan pemikiran secara detail untuk menyelesaikan masalah dan membuat keputusan dengan tujuan sebagai kompetensi aktivitas sehari-hari dan masa yang akan datang. Pembelajaran yang sesuai berpikir kritis adalah pembelajaran matematika yang berlevel High Order Thinking Skills (HOTS) yaitu proses berpikir tinggi dalam menyelesaikan masalah matematika yang mencakup proses menganalisa (C4), dan mengevaluasi (C5). Penelitian ini bertujuan untuk mengetahui kemampuan berpikir kritis siswa dalam menyelesaikan soal High Order Thinking Skills (HOTS). Metode yang digunakan adalah deskriptif kualitatif menggunakan deskripsi untuk memecahkan masalah berdasarkan data-data pada saat penelitian dengan populasi siwa kelas X SMA N 1 Kasiman tahun ajaran 2019/2020, dan sampel 3 siswa yang diambil dari jurusan IPA. Dari hasil penelitian siswa 1 dapat terpenuhi indikator berpikir kritis (Focus, Reason, inference, Situation, Clarity, dan Overview), sedangkan siswa 2 memenuhi indikator berpikir kritis (Focus, Reason, dan inference,) sedangkan siswa 3 memenuhi indikator berpikir kritis (Focus dan Reason).
\end{abstract}

Kata Kunci: Berpikir Kritis, HOTS.

\begin{abstract}
Critical Thinking is an activity that requires detailed thinking to solve problems and make decisions with the aim of being the competence of daily activities and the future. Learning that is a accordance with critical thinking is high level mathematic leraning High Order Thinking Skills (HOTS) namely the High Order Thinking process in solving mathematic problems that includes the process of analyze and evaluate. The study aims to determine students critical skills in solving High Order Thinking Skills (HOTS) questions. The method used is descriptive qualitative using
\end{abstract}


descriptive methods to solve problems based on the data at the time of the study with a population of class X SMA N 1 KASIMAN school year 2019/2020, a sample of three students taken from the science department. From the research results, one can meet the critical thinking indikator focus, reason, inference, situation, clarity and overiew, while student two meets the critical thinking focus, reason and situation, and the student three alsomeets the critical thinking indicator focus and reason .

Keywords: Critical Thinking, Hihg Order Thinking Skills (HOTS). 


\section{PENDAHULUAN}

Sedarmayanti (2001) menjelaskan bahwa melalui pendidikan, seseorang dapat mempersiapkan untuk memiliki bekal agar siap, mengenal dan mengembangkan metode berpikir kritis secara sistematik dan dapat memecahkan masalah yang akan dihadapi dalam kehidupan dikemudian hari. Soedjadi (2000) tujuan diberikan pembelajaran matematika di jenjang pendidikan Sekolah Dasar dan pendidikan umum adalah untuk mempersiapkan peserta didik untuk lebih mengerti tentang matematika dan pola pikir akan berkembang dalam kehidupan sehari-hari sehingga dapat mempelajari berbagai ilmu pengetahuan. Selain itu, salah satu yang perlu ditekankan dalam pembelajaran matematika menurut kurikulum 2013 adalah melatih kemampuan berpikir siswa untuk membuat generalisasi fakta, data dankemampua yang bersifat logis(Permendikbud, No 24;2016).

Jensen (2011) berpikir kritis berarti proses mental seseorang yang efektif dan handal, yang digunakan untuk mengetahui pengetahuan yang relevan dan benar tentang dunia. Sedangkan Renick (1987) Mengutarakan bahwa kemampuan berpikir tingkat tinggi merupakan suatu pemikiran yang kompleks dengan melibatkan berbagai sumber dan kriteria sehingga dapat menyelesaikan masalah yang ada

High Order Thinking Skills merupakan keterampilan berpikir yang lebih tinggi yang terjadi ketika seseorang mengambil informasi baru dan menyimpan kedalam memori yang saling berkaitan serta mengatur ulang dan memperluas informasi tersebut untuk mencapai suatu tujuan atau menemukan sesuatu masalah lewis \& Smith (1993). Tujuan utama dari High Order Thinking Skills adalah meningkatkan kemampuan berpikir peserta didik pada level yang lebih tinggi, terutama yang berkaitan dengan kemampuan berpikir kritis, kreatif dalam menerima berbagai jenis informasi, berpikir kreatif dalam memecahkan suatu permasalahan dapat menggunakan berbagai pengetahuan, informasi yang dimiliki serta dapat membuat keputusan dalam situasi yang kompleks (Saputra 2016). 
Tabel 1. Kriteria dan Indikator berpikir Kritis

\begin{tabular}{lll}
\hline Kriteria & Indikator \\
Berpikir kritis & \\
\hline $\mathrm{F}$ (Focus) & Siswa dapat memahami \\
& $\begin{array}{l}\text { permasalahan pada soal yang } \\
\text { diberikan. }\end{array}$ \\
\hline $\mathrm{R}$ (Reason) & Siswa dapat memberikan alasan \\
& berdasarkan fakta/bukti yang \\
& relevan pada setiap langkah- \\
& langkah dalam membuat \\
& keputusan. \\
\hline $\mathrm{I}$ (Inference) & Siswa membuat kesimpulan yang \\
& sesuai permasalahan \\
& Siswa memilih reason yang tepat \\
& untuk tercapainya kesimpulan \\
& yang dibuat. \\
\hline $\mathrm{S}($ Situation) & Siswa menggunakan informasi \\
& yang sesuai dengan permasalahan. \\
\hline $\mathrm{C}$ (Clarity) & Siswa memberikan penjelasan \\
& lebih rinci \\
\hline $\mathrm{O}$ (Qverview) & Siswa mengecek kembali secara \\
& menyeluruh. \\
\hline
\end{tabular}

Jenis penelitian yang digunakan oleh peneliti adalah deskriptif kualitatif. Subjek penelitian adalah siswa kelas $\mathrm{X}$ SMA Negeri 1 Kasiman Bojonegoro yang berjumlah 3 siswa yang diambil dari nilai raport dari 10 besar. Pengumpulan data dalam penelitian ini menggunakan tes dan wawancara. Instrumen yang digunakan peneliti adalah lembar tes dan lembar wawancara. Jenis tes yang digunakan dalam penelitian ini adalah tes tulis. Triangulasi data dalam penelitian ini menggunakan triangulasi metode

\section{HASIL DAN PEMBAHASAN}

Hasil kemampuan berpikir kritis siswa sesuai Indikator berpikir kritis pada setiap subjek.

a. Soal High Order Thinking Skills (HOTS) pada level C4 (Menganalisa) terdapat pada soal tes nomor 1. Siswa 1, 2 dan 3 memenuhi kemampuan berpikir kritis pada indikator focus, reason, inference, situation, Clarity dan Oerview karena jawaban setiap siswa sudah sesuai dengan kunci jawaban peneliti.

b. Soal High Order Thinking Skills (HOTS) pada level C4 (Menganalisa) juga terdapat pada soal tes nomor 2. Pada siswa 1, 2 dan 3 kemampuan berpikir siswa sesuai dengan indikator berpikir kritis focus, reason, inference, situation, clarity, dan overview karena pada soal tes yang diberikan peneliti jawaban siswa benar.

c. Soal High Order Thinking Skills (HOTS) pada level C5 (mengevaluasi) terdapat pada soal tes nomor 3. Untuk siswa 1 dan 2 kemampuan berpikir kritisnya sudah sesuai dengan indikator berpikir kritis focus, reason, inference, 
situation, clarity dan overview dan untuk siswa 3 hanya memenuhi indikator berpikir kritis focus, reason, inference, situation dan clarity, dan tidak memenuhi indikator berpikir kritis overview karena pengecekan yang dilakukan siswa memang sudah benar tetapi siswa belum menjumlahkan hasil akhir soal tes nomor 3 .

Soal High Order Thinking Skills (HOTS) pada level C5 (Mengevaluasi) terdapat pada soal tes nomor 4. Untuk siswa 1 memenuhi indikator berpikir kritis focus, reason, inference, situation, clarity dan overview. Siswa 2 memenuhi indikator berpikir kritis focus, reason dan inference tidak memenuhi indikator berpikir kritis situation, clarity dan overview karena siswa sepenuhnya belum mendapatkan informasi dari soal tes dan belum bisa mengerjakan sampai selesai, untuk siswa 3 hanya memenuhi 2 indikator berpikir kritis saja yaitu focus dan reason dan tidak memenuhi indikator berpikir kritis inference, situation, clarity dan overview karena siswa tidak bisa mengerjakan dari soal tes
Indikator berpikir kritis yang belum dicapai oleh sebagian besar subjek penelitiandalam penelitian ini yaitu clarity(memberikan penjelasan lebh rinci) dan overview (menegecek kembali secara menyeluruh mulai dari awal sampai akhir) sesuai indikator berpikir kritis yang disampaikan Ennis (2011).Hal ini didukung Fisher (2008) yang menjelaskan dalam berpikir kritis siswa dituntut berpikir yang tidak langsung mengarah ke kesimpulan begitu saja tanpa sungguh-sungguh memikirkannya dan berpikir kritis menuntut evaluasi yang terdapat dalam overview terhadap sumber informasi yang telah digunakan. Kemampuan subjek dalam menyelesaikan soal tingkat evaluasi pada penelitian ini juga masih rendah sesuaidengan penelitian yang dilakukan oleh Nuragni (2018) bahwa dalam menyelesaikan soal HOTmasih rendah karena siswa masih kesulitan di dalam menyelesaiakan soal tingkat evaluasi. 


\section{SIMPULAN}

Dapat dilihat dari hasil tes yang diperoleh dan dapat dilihat di indikator masingmasing berpikir kritis, yakni subjek 1 memenuhi 6 indikator berpikir kritis yaitu focus, reason, inference, situation, clarity dan overview. Subjek 2 memenuhi indikator sebagai sebagai berikut focus, reason, inference, situation, clarity, dan overview, tetapi ada beberapa indikator yang belum dicapai oleh subjek 2 dari soal tes no.4 yaitu clarity dan overview karena kurang teliti dalam menyelesaikan soal dan subjek 3 memenuhi indikator berpikir kritis focus, reason, inference, situation, clarity dan overview, dan tetapi subjeck 3 ada yang belum memenuhi indikator pada soal no.3 dan no.4 pada indikator situation, clarity dan overview karena kurangnya mampu dalam mengerjakan soal level tinggi

\section{DAFTAR PUSTAKA}

Eric, J. (2011). Pembelajaran Berbasis Otak (Edisi Kedua). Jakarta: Indeks Permata Puri Media.

Permendikbud. (2016). Peraturan MenteriPendidikan dan Kebudayaan Nomor 24 Tahun 2016 Tentang Kompetensi Inti dan Kompetensi Dasar Pelajaran Pada Kurikulum 2013 Pada Pendidikan Dasar Dan Pendidikan Menengah
Resnick, L. (1987). Education and Learning to Think. Washington, D.C: National Academy Press.

Saputra, H. (2016). Pengembangan Mutu Pendidikan Menuju Era Global: Penguatan Mutu Pembelajaran Dengan Penerapan HIGH Order Thinking Skils (HOTS). Bandung: SMILE's Publising.

Sedarmayanti. (2001). Sumber Daya Manusia dan Produktivitas Kerja. Jakarta: Mandar Maju.

Smith, L. \& Smith, D. (1993). Defiing High Order Thinking Theory Into Practice Collage of Education. Ohio: The Ohio State University.

Soedjadi. (2000). Kiat Pendidikan Matematika di Indonesia. Jakarta: Direktoral Jendral Pendidikan Tinggi Departemen Pendidikan Nasional 